\title{
Aeromicrobium flavum sp. nov., isolated from air
}

\author{
Correspondence \\ Chengxiang Fang \\ cxfang@whu.edu.cn
}

\author{
Yali Tang, Guoling Zhou, Lei Zhang, Jing Mao, Xuesong Luo, \\ Mengxi Wang and Chengxiang Fang
}

College of Life Sciences, Wuhan University, Wuhan 430072, PR China

\begin{abstract}
A Gram-positive, non-motile, facultatively anaerobic actinobacterium, designated TYLN1 ${ }^{\top}$, was isolated from an air sample from the campus of Wuhan University, China, and subjected to a polyphasic taxonomic study. Strain TYLN1 ${ }^{\top}$ grew optimally at $\mathrm{pH} 7.0$ and $30^{\circ} \mathrm{C}$. Analysis of $16 \mathrm{~S}$ rRNA gene sequence similarities revealed that the organism belongs to the genus Aeromicrobium. The $\mathrm{G}+\mathrm{C}$ content of the strain was $73.3 \mathrm{~mol} \%$. The cell-wall diamino acid was LL-2,6-diaminopimelic acid, the predominant menaquinones were MK- $9\left(\mathrm{H}_{4}\right)$ and MK- $8\left(\mathrm{H}_{4}\right)$ and the predominant fatty acid was $\mathrm{C}_{18: 1} \omega 9 c(68.38 \%)$. These chemotaxonomic data also support the affiliation of strain $\mathrm{TYLN}^{\top}{ }^{\top}$ to the genus Aeromicrobium. The values for DNA-DNA hybridization between strain $\operatorname{TYLN}^{\top}{ }^{\top}$ and the phylogenetically closest relatives Aeromicrobium tamlense DSM $19087^{\top}$ and Aeromicrobium panaciterrae DSM $17939^{\top}$ were respectively 35 and $11.5 \%$. On the basis of the data from this study, the isolate represents a novel species, for which the name Aeromicrobium flavum sp. nov. is proposed. The type strain is $\operatorname{TYLN}^{\top}{ }^{\top}$ (=CCTCC AB $206046^{\top}=$ DSM $19355^{\top}$ ).
\end{abstract}

The genus Aeromicrobium was proposed by Miller et al. (1991) and its description was later emended by Yoon et al. (2005). At the time of writing, the genus comprises seven species, Aeromicrobium erythreum (Miller et al., 1991) (the type species), A. alkaliterrae (Yoon et al., 2005), A. fastidiosum (Tamura \& Yokota, 1994), A. marinum (Bruns et al., 2003), A. panaciterrae (Cui et al., 2007), A. ponti (Lee \& Lee, 2008) and A. tamlense (Lee \& Kim, 2007). In our research into the isolation and identification of environmental microbes, we noticed that a strain named TYLN $^{\mathrm{T}}$ formed a distinct branch within the Aeromicrobium clade, implying that it might represent a novel species. Polyphasic analysis of morphological, physiological, biochemical and chemotaxonomic properties was therefore undertaken to substantiate the result of the phylogenetic analysis.

An air sample was collected on the campus of Wuhan University using a Petri dish with TGY agar (a tryptone/ glucose/yeast extract medium often used for growth of Deinococcus species; Brim et al., 2003). After sampling, the plate was incubated at $30{ }^{\circ} \mathrm{C}$ for 1 week and strain TYLN $1{ }^{\mathrm{T}}$ was recovered.

Chromosomal DNA preparation and 16S rRNA gene amplification were carried out according to the protocol of Niemann et al. (1997). Analysis of the 16S rRNA gene sequence was performed by using the software package MEGA version 3.1 (Kumar et al., 2001) after multiple

The GenBank/EMBL/DDBJ accession number for the 16S rRNA gene sequence of strain TYLN1 ${ }^{\top}$ is EF133690. alignment of the data by CLUSTAL_X (Thompson et al., 1997). The model of Jukes \& Cantor (1969) was used to compute evolutionary distances, based on which, a phylogenetic tree was built using the neighbour-joining method (Saitou \& Nei, 1987) with bootstrap analysis of 1000 replications. Sequence-similarity calculations indicated that strain TYLN1 ${ }^{\mathrm{T}}$ showed the greatest degree of sequence similarity to the type strains of $A$. tamlense (98.4\%), A. panaciterrae (97.1\%), A. fastidiosum (96.4\%), A. alkaliterrae $(96.2 \%)$, A. marinum $(96.2 \%)$ and $A$. erythreum (96.1\%). Lower sequence similarities $(<95 \%)$ were found with respect to members of all other genera shown in Fig. 1.

Based on 16S rRNA gene sequence similarity, DNA-DNA hybridization between strain TYLN1 $1^{\mathrm{T}}$ and the type strains of A. tamlense and A. panaciterrae was assessed. DNADNA hybridization tests were carried out by Dr Cathrin Spröer (DSMZ, Braunschweig, Germany). DNA was isolated using a French pressure cell (Thermo Spectronic) and purified by chromatography on hydroxyapatite as described by Cashion et al. (1977). DNA-DNA hybridization was carried out as described by De Ley et al. (1970) under consideration of the modifications described by $\mathrm{Hu}$ et al. (1983) using a model Cary 100 Bio UV/Vis spectrophotometer equipped with a Peltier-thermostatted $6 \times 6$ multicell changer and a temperature controller with in-situ temperature probe (Varian). Strain TYLN $1^{\mathrm{T}}$ showed $35 \%$ reassociation with $A$. tamlense DSM $19087^{\mathrm{T}}$ and $11.5 \%$ with $A$. panaciterrae DSM $17939^{\mathrm{T}}$; these values are much lower than the recommended threshold of $70 \%$ for 


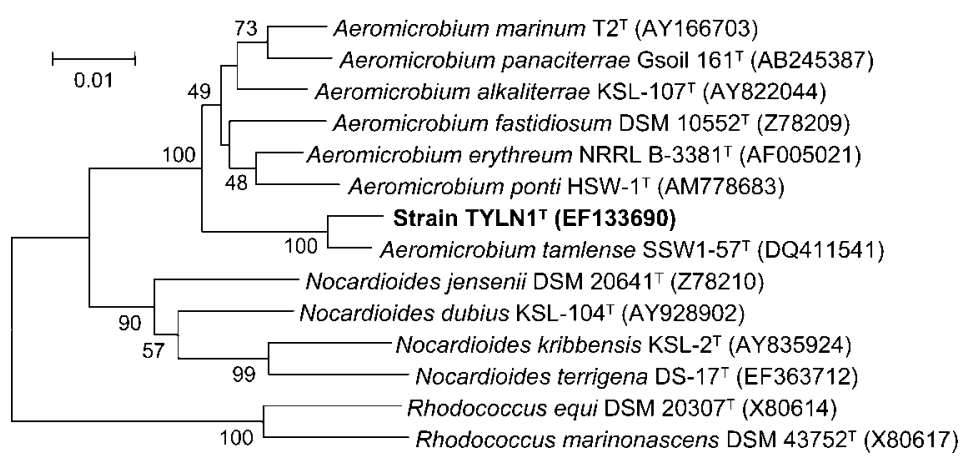

Fig. 1. Neighbour-joining tree, showing the phylogenetic positions of strain TYLN1 ${ }^{\mathrm{T}}$ and related taxa, based on 16S rRNA gene sequences. GenBank accession numbers are given. Bootstrap analysis was made with 1000 resamplings; percentages of support are shown at nodes. Bar, $1 \%$ sequence divergence. the delineation of genomic species (Wayne et al., 1987). The results of the DNA-DNA hybridization experiments therefore indicate that strain $\mathrm{TYLN1}^{\mathrm{T}}$ represents a novel species.

Cell morphology was examined by phase-contrast and transmission electron microscopy. For transmission electron microscopy, cells were negatively stained with $1 \%$ (w/v) phosphotungstic acid after air drying. Cells were irregular rods, $0.2-0.4 \mu \mathrm{m}$ wide and $0.3-1.2 \mu \mathrm{m}$ long (Fig. 2). No flagella were observed.

Growth at various $\mathrm{NaCl}$ concentrations $(0.1-2 \%$, w/v) was investigated using LB broth. The $\mathrm{pH}$ range for growth was determined using LB broth that was adjusted to $\mathrm{pH}$ 5-10 at intervals of $1 \mathrm{pH}$ unit. Growth at different temperatures (4, $11,25,28,30,37,42$ and $50{ }^{\circ} \mathrm{C}$ ) was tested on LB agar. Gram staining was performed as described by Gerhardt et al. (1994). Antimicrobial susceptibility testing was performed by the agar-diffusion method using antibioticimpregnated discs as described by Buczolits et al. (2002). Oxidation of $N^{\prime}, N^{\prime}, N^{\prime}, N^{\prime}$-tetramethyl $p$-phenylenediamine was used to determine oxidase activity. Catalase activity was determined using $3 \%(\mathrm{v} / \mathrm{v}) \mathrm{H}_{2} \mathrm{O}_{2}$ solution. Hydrolysis
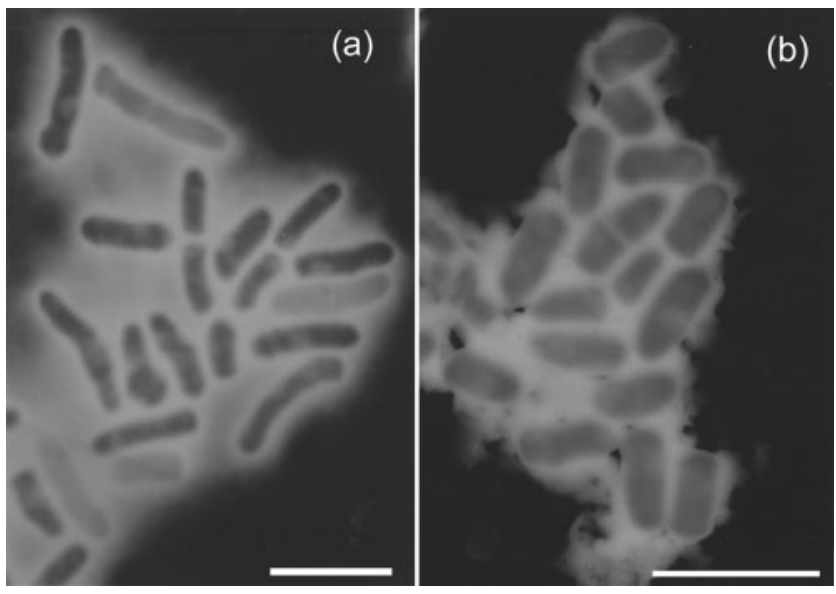

Fig. 2. Transmission electron micrographs of cells of strain $\mathrm{TYLN1}^{\top}$. Cells were grown on LB agar plates at $30{ }^{\circ} \mathrm{C}$ for $16 \mathrm{~h}$ (a) and $48 \mathrm{~h}$ (b). Bars, $1 \mu \mathrm{m}$. of casein was tested as described by MacFaddin (1980). The ability to use different carbon sources was analysed with the Biolog GP2 Microplate system according to the instructions of the manufacturer. Other physiological and biochemical properties were tested using the API ZYM, API 20E and API 20NE systems (bioMérieux), according to the instructions of the manufacturer.

Strain TYLN $1^{\mathrm{T}}$ exhibited nitrate reduction activity, which has not been reported previously for species of the genus Aeromicrobium (Miller et al., 1991; Tamura \& Yokota, 1994; Bruns et al., 2003; Yoon et al., 2005; Cui et al., 2007; Lee \& Kim, 2007). The main physiological and biochemical properties are given in Table 1 and the species description. Features that differentiate strain TYLN $1^{\mathrm{T}}$ from $A$. tamlense are shown in Table 2 .

The isomer type of the diamino acid in the cell-wall peptidoglycan was analysed using TLC according to the method described by Komagata \& Suzuki (1987). Extraction of menaquinones and determination of the menaquinone composition were carried out as described by Collins (1985). The thermal denaturation method (Mandel \& Marmur, 1968) was used to determine the $\mathrm{G}+\mathrm{C}$ content of the genomic DNA spectrophotometrically (DU800 spectrophotometer; Beckman Coulter). Strain TYLN $^{\mathrm{T}}$ contained LL-diaminopimelic acid as the diagnostic diamino acid in the cell wall. The major isoprenoid quinones were $\mathrm{MK}-9\left(\mathrm{H}_{4}\right) \quad(74.6 \%)$ and $\mathrm{MK}-8\left(\mathrm{H}_{4}\right)$ $(25.4 \%)$. The DNA G $+\mathrm{C}$ content was $73.3 \mathrm{~mol} \%$.

Preparation and analysis of cellular fatty acid methyl esters were performed using the Sherlock Microbial Identification System (version 6.0; MIDI), according to the instructions of the manufacturer. Strain TYLN1 ${ }^{\mathrm{T}}$ was grown for $24 \mathrm{~h}$ at $30{ }^{\circ} \mathrm{C}$ on trypticase soy broth (Difco) supplemented with Bacto agar (Difco). The cellular fatty acid profile of strain TYLN ${ }^{\mathrm{T}}$ was characterized by the presence $(>1 \%)$ of $\mathrm{C}_{18: 1} \omega 9 c(68.38 \%), \mathrm{C}_{18: 0}(11.69 \%), \mathrm{C}_{16: 0}(8.66 \%), \mathrm{C}_{16: 0}$ 2-OH (5.26\%), 10-methyl $\mathrm{C}_{18: 0}(2.28 \%)$ and $\mathrm{C}_{16: 1} \omega 6 c$ $(1.03 \%)$ acids. The presence of $\mathrm{C}_{18: 1} \omega 9 \mathrm{c}$ as the predominant component of the fatty acid composition is similar to A. tamlense but unlike other Aeromicrobium species (Miller et al., 1991; Tamura \& Yokota, 1994; Bruns et al., 2003; Yoon et al., 2005; Cui et al., 2007; Lee \& Kim, 2007). 
Table 1. Phenotypic characteristics of strain $\operatorname{TYLN}^{\top}{ }^{\top}$ and species of the genus Aeromicrobium

Taxa: 1, strain TYLN1 ${ }^{\mathrm{T}}$ (A. flavum sp. nov.); 2, A. tamlense (data from Lee \& Kim, 2007); 3, A. erythreum (Miller et al., 1991; Tamura \& Yokota, 1994); 4, A. fastidiosum (Collins \& Stackebrandt, 1989; Tamura \& Yokota, 1994); 5, A. panaciterrae (Cui et al., 2007); 6, A. marinum (Bruns et al., 2003); 7, A. alkaliterrae (Yoon et al., 2005). +, Positive; -, negative; w, weakly positive; ND, no data available.

\begin{tabular}{|c|c|c|c|c|c|c|c|}
\hline Characteristic & 1 & 2 & 3 & 4 & 5 & 6 & 7 \\
\hline Cell morphology & Irregular rods & Irregular rods & Irregular rods, cocci & Rods, cocci & Rods & Rods & Rods, cocci \\
\hline Motility & - & - & - & + & - & - & + \\
\hline Oxidase & + & - & + & + & - & + & - \\
\hline Urease & $\mathrm{W}$ & - & - & - & - & $\mathrm{ND}$ & - \\
\hline Nitrate reduction & + & - & - & $\mathrm{ND}$ & - & - & - \\
\hline \multicolumn{8}{|l|}{ Growth at: } \\
\hline $10{ }^{\circ} \mathrm{C}$ & - & + & - & + & - & + & + \\
\hline $42{ }^{\circ} \mathrm{C}$ & - & + & - & - & - & - & - \\
\hline \multicolumn{8}{|l|}{ Hydrolysis of: } \\
\hline Casein & - & - & + & + & - & - & + \\
\hline Aesculin & + & + & + & $\mathrm{ND}$ & $\mathrm{ND}$ & $\mathrm{ND}$ & - \\
\hline $\begin{array}{l}\text { DNA G + C content } \\
(\mathrm{mol} \%)\end{array}$ & 73.3 & 72.7 & $71-73$ & $71-72$ & 65.5 & 70.6 & 71.5 \\
\hline
\end{tabular}

Comparative 16S rRNA gene sequence analysis showed that strain TYLN $^{\mathrm{T}}$ is most closely related to the genus Aeromicrobium of the family Nocardioidaceae (Fig. 1). Chemotaxonomic properties support the monothetic phylogenetic classification of strain TYLN1 ${ }^{\mathrm{T}}$ as a member of the genus Aeromicrobium. However, the isolate exhibited phenotypic, phylogenetic and genetic distinctiveness.

Taken together, the evidence provided by $16 \mathrm{~S}$ rRNA gene sequencing, DNA-DNA hybridization, phenotypic characterizations and chemotaxonomic data indicates that

Table 2. Physiological characteristics that differentiate strain TYLN1 ${ }^{\top}$ from A. tamlense NRRL B-24466 ${ }^{\top}$

Data were obtained in this study. +, Positive; w, weakly positive; -, negative.

\begin{tabular}{|lcc|}
\hline Characteristic & Strain TYLN1 $^{\mathbf{T}}$ & $\begin{array}{c}\text { A. } \text { tamlense } \\
\text { NRRL B-24466 }\end{array}$ \\
\hline Biolog GP2 plate response for: & & \\
Tween 80 & - & + \\
Uridine & - & + \\
Thymidine & - & + \\
L-Rhamnose & - & + \\
Dextrin & - & + \\
Pyruvic acid & + & - \\
$\gamma$-Hydroxybutyric acid & + & $\mathrm{W}$ \\
API ZYM test results & & + \\
Alkaline phosphatase & - & + \\
Acid phosphatase & - & $\mathrm{W}$ \\
Trypsin & - & $\mathrm{W}$ \\
Naphthol-AS-BI-phosphohy- & - & - \\
drolase & & - \\
Esterase (C4) & & \\
$\beta$-Glucosidase & + & \\
\hline
\end{tabular}

strain TYLN ${ }^{\mathrm{T}}$ represents a novel species, for which the name Aeromicrobium flavum sp. nov. is proposed.

\section{Description of Aeromicrobium flavum sp. nov.}

Aeromicrobium flavum (fla'vum. L. neut. adj. flavum yellow, referring to the colony colour).

Cells are Gram-positive, non-motile and facultatively anaerobic. Colonies are circular, smooth, entire and yellow pigmented. Growth occurs at $25-37{ }^{\circ} \mathrm{C}$ and at $\mathrm{pH} 5-10$. Optimal growth at $30{ }^{\circ} \mathrm{C}$ and $\mathrm{pH}$ 7. Tolerates $4 \% \mathrm{NaCl}$ in the medium; the optimum $\mathrm{NaCl}$ concentration for growth is $1-2 \%$. Catalase- and oxidase-positive. Aesculin is hydrolysed, but not casein. In API 20E and API 20NE tests, urease is weakly positive. Gelatin liquefaction is observed. $\mathrm{H}_{2} \mathrm{~S}$ and indole are not produced. Nitrate is reduced to nitrite. Voges-Proskauer reaction is weakly positive. The following enzyme activities are not detected: arginine dihydrolase, lysine decarboxylase, ornithine decarboxylase and tryptophan deaminase. The fatty acid profile comprises $\mathrm{C}_{18: 1} \omega 9 \mathrm{c}(68.38 \%), \mathrm{C}_{18: 0}(11.69 \%)$, $\mathrm{C}_{16: 0}(8.66 \%), \mathrm{C}_{16: 0} 2-\mathrm{OH}(5.26 \%), 10$-methyl $\mathrm{C}_{18: 0}$ $(2.28 \%)$ and $\mathrm{C}_{16: 1} \omega 6 c(1.03 \%)$. Positive responses in the Biolog GP2 plate for maltose, D-psicose, D-ribose, sucrose, trehalose, turanose, D-fructose, $\alpha$-D-glucose, acetic acid, $\alpha$ ketovaleric acid, $\gamma$-hydroxybutyric acid, pyruvic acid, D-fructose 6-phosphate and glycerol; negative for $\alpha$ cyclodextrin, dextrin, glycogen, inulin, mannan, Tween 80 , $N$-acetyl-D-glucosamine, $N$-acetyl- $\beta$-D-mannosamine, amygdalin, D-xylose, L-arabinose, D-arabitol, cellobiose, Lfucose, L-rhamnose, D-mannose, L-alanyl glycine, arbutin, L-asparagine, 2'-deoxyadenosine, salicin, L-lactic acid, methyl $\alpha$-D-mannoside, putrescine, sedoheptulosan, xylitol, glycyl L-glutamic acid, $\alpha$-hydroxybutyric acid, $\beta$-hydroxybutyric acid, thymidine and uridine. In API ZYM tests, esterase (C4), esterase lipase (C8), leucine arylamidase, 
$\alpha$-glucosidase and $\beta$-glucosidase are detected. NaphtholAS-BI-phosphohydrolase, alkaline and acid phosphatase, valine arylamidase, cystine arylamidase, $\alpha$-chymotrypsin, $\alpha$ galactosidase, $\beta$-galactosidase, $\beta$-glucuronidase, $N$-acetyl$\beta$-glucosaminidase, $\alpha$-mannosidase, $\alpha$-fucosidase and trypsin tests are negative. Lipase (C14) is weakly positive. Resistant to penicillin and nalidixic acid and susceptible to tetracycline, chloramphenicol, kanamycin, vancomycin, erythromycin, rifampicin and tobramycin. The major menaquinones are MK- $9\left(\mathrm{H}_{4}\right)$ and $\mathrm{MK}-8\left(\mathrm{H}_{4}\right)$. Cell-wall peptidoglycan is based on LL-2,6-diaminopimelic acid. The DNA G $+\mathrm{C}$ content of the type strain is $73.3 \mathrm{~mol} \%$.

The type strain, TYLN1 ${ }^{\mathrm{T}}$ (=CCTCC AB $206046^{\mathrm{T}}=$ DSM $\left.19355^{\mathrm{T}}\right)$, was isolated from air.

\section{Acknowledgements}

We are grateful to Dr David P. Labeda for providing the type strain of Aeromicrobium tamlense and Dr Akira Yokota for his technical support with menaquinone composition analysis. This work was supported by the R \& D Infrastructure and Facility Development Program from the Ministry of Science and Technology of the People's Republic of China (grant no. 2005DKA21208).

\section{References}

Brim, H., Venkateswaran, A., Kostandarithes, H. M., Fredrickson, J. K. \& Daly, M. J. (2003). Engineering Deinococcus geothermalis for bioremediation of high-temperature radioactive waste environments. Appl Environ Microbiol 69, 4575-4582.

Bruns, A., Philipp, H., Cypionka, H. \& Brinkhoff, T. (2003). Aeromicrobium marinum sp. nov., an abundant pelagic bacterium isolated from the German Wadden Sea. Int J Syst Evol Microbiol 53, 1917-1923.

Buczolits, S., Denner, E. B. M., Vybiral, D., Wieser, M., Kämpfer, P. \& Busse, H.-J. (2002). Classification of three airborne bacteria and proposal of Hymenobacter aerophilus sp. nov. Int J Syst Evol Microbiol 52, 445-456.

Cashion, P., Holder-Franklin, M. A., McCully, J. \& Franklin, M. (1977). A rapid method for the base ratio determination of bacterial DNA. Anal Biochem 81, 461-466.

Collins, M. D. (1985). Isoprenoid quinone analysis in bacterial classification and identification. In Chemical Methods in Bacterial Systematics, pp. 267-287. Edited by M. Goodfellow \& D. E. Minnikin. London: Academic Press.

Collins, M. D. \& Stackebrandt, E. (1989). Molecular taxonomic studies on some LL-diaminopimelic acid-containing coryneforms from herbage: description of Nocardioides fastidiosa sp. nov. FEMS Microbiol Lett 57, 289-294.

Cui, Y. S., Im, W. T., Yin, C. R., Lee, J. S., Lee, K. C. \& Lee, S. T. (2007). Aeromicrobium panaciterrae sp. nov., isolated from soil of a ginseng field in Korea. Int J Syst Evol Microbiol 57, 687-691.
De Ley, J., Cattoir, H. \& Reynaerts, A. (1970). The quantitative measurement of DNA hybridization from renaturation rates. Eur $J$ Biochem 12, 133-142.

Gerhardt, P., Murray, R. G. E., Wood, W. A. \& Krieg, N. R. (1994). Methods for General and Molecular Bacteriology. Washington, DC: American Society for Microbiology.

Huß, V. A. R., Festl, H. \& Schleifer, K. H. (1983). Studies on the spectrophotometric determination of DNA hybridization from renaturation rates. Syst Appl Microbiol 4, 184-192.

Jukes, T. H. \& Cantor, C. R. (1969). Evolution of protein molecules. In Mammalian Protein Metabolism, pp. 21-132. Edited by H. N. Munro. New York: Academic Press.

Komagata, K. \& Suzuki, K. (1987). Lipid and cell-wall analysis in bacterial systematics. Methods Microbiol 19, 161-207.

Kumar, S., Tamura, K., Jakobsen, I.-B. \& Nei, M. (2001). MEGA2: molecular evolutionary genetics analysis software. Bioinformatics 17, 1244-1245.

Lee, S. D. \& Kim, S. J. (2007). Aeromicrobium tamlense sp. nov., isolated from dried seaweed. Int J Syst Evol Microbiol 57, 337-341.

Lee, D. W. \& Lee, S. D. (2008). Aeromicrobium ponti sp. nov., isolated from seawater. Int J Syst Evol Microbiol 58, 987-991.

MacFaddin, J. F. (1980). Biochemical Tests for Identification of Medical Bacteria, 2nd edn. Baltimore: Williams \& Wilkins.

Mandel, M. \& Marmur, J. (1968). Use of ultraviolet absorbancetemperature profile for determining the guanine plus cytosine content of DNA. Methods Enzymol 12B, 195-206.

Miller, E. S., Woese, C. R. \& Brenner, S. (1991). Description of the erythromycin-producing bacterium Arthrobacter sp. strain NRRL B3381 as Aeromicrobium erythreum gen. nov., sp. nov. Int J Syst Bacteriol 41, 363-368.

Niemann, S., Pühler, A., Tichy, H.-V., Simon, R. \& Selbitschka, W. (1997). Evaluation of the resolving power of three different DNA fingerprinting methods to discriminate among isolates of a natural Rhizobium meliloti population. J Appl Microbiol 82, 477-484.

Saitou, N. \& Nei, M. (1987). The neighbor-joining method: a new method for reconstructing phylogenetic trees. Mol Biol Evol 4, 406-425.

Tamura, T. \& Yokota, A. (1994). Transfer of Nocardioides fastidiosa Collins and Stackebrandt 1989 to the genus Aeromicrobium as Aeromicrobium fastidiosum comb. nov. Int J Syst Bacteriol 44, 608-611.

Thompson, J. D., Gibson, T. J., Plewniak, F., Jeanmougin, F. \& Higgins, D. G. (1997). The CLUSTAL_X windows interface: flexible strategies for multiple sequence alignment aided by quality analysis tools. Nucleic Acids Res 25, 4876-4882.

Wayne, L. G., Brenner, D. J., Colwell, R. R., Grimont, P. A. D., Kandler, O., Krichevsky, M. I., Moore, L. H., Moore, W. E. C., Murray, R. G. E. \& other authors (1987). International Committee on Systematic Bacteriology. Report of the ad hoc committee on reconciliation of approaches to bacterial systematics. Int $J$ Syst Bacteriol 37, 463-464.

Yoon, J. H., Lee, C. H. \& Oh, T. K. (2005). Aeromicrobium alkaliterrae sp. nov., isolated from an alkaline soil, and emended description of the genus Aeromicrobium. Int J Syst Evol Microbiol 55, 2171-2175. 